technical (audio and video) to humanitarian and educational (the formation of critical thinking, legal culture, focused on the idea of human rights, etc.).

Key words: corruption, sources of corruption, corruption counteraction, law, culture, cultural approach. державно-правових дисциилін Луганського державного університету внутрішніх справ імені Е.О. Дідоренка

(м. Сєвєродонецьк, Украӥна)

\title{
УДОСКОНАЛЕННЯ ПРАВОВОГО РЕГУЛЮВАННЯ ПРОВЕДЕННЯ ГРОМАДСЬКОЇ ЕКСПЕРТИЗИ ДІЯЛЬНОСТІ ОРГАНІВ МІСЦЕВОГО САМОВРЯДУВАННЯ В УКРАЇНІ
}

У статті розкрито питання удосконалення правового регулювання проведення громадської експертизи діяльності органів місцевого самоврядування в Україні. Вказується, що конституційно-правове регулювання проведення громадської експертизи почалося в окремих сферах діяльності органів публічної влади вже 3 перших років здобуття незалежності України. Проведення громадської експертизи є важливою формою взаємодії громадськості та органів місцевого самоврядування при прийнятті нормативно-правових актів, сприяє залученню різних соціальних і корпоративних груп експертну грошову оцінку не тільки діяльності органів місцевого самоврядування, а й прийнятих ними рішень i наслідків їх впровадження. Відзначено, що найбільш вразливим питанням в правовому регулюванні громадської експертизи діяльності органів місцевого самоврядування є її недостатня правова визначеність на рівні законодавчих актів.

Ключові слова: правове регулювання, громадська експертиза, громадськість, органи публічної влади, органи місцевого самоврядування, Україна.

Постановка проблеми. Конституційно-правове регулювання проведення громадської експертизи в Україні розпочалося в окремих сферах діяльності органів публічної влади вже з перших років здобуття незалежності нашою державою. Серед сфер, які отримали спеціальне законодавче регламентування проведення у них громадської експертизи, варто назвати охорону здоров'я, екологічну, наукову та науково-технічну. Трохи згодом проведення громадської експертизи починає здійснюватися й на рівні органів місцевого самоврядування.

Аналіз останніх досліджень і публікацій. Питання удосконалення правового регулювання проведення громадської експертизи діяльності органів місцевого самоврядування в Україні отримало своє відображення у наукових працях таких вітчизняних вчених як В. Купрій, Л. Паливода [1], О. Літвінов, О. Тинкован, Н. Літвінова [2], Н. Мішина [3], Л. Усаченко [4], В. Федоренко [5] тощо. Питання видів громадської експертизи було розкрито автором у попередніх публікаціях [6]. Попри наявні публікації у вітчизняній юридичній науці, які присвячені конституційно-правовому утвердженню 
громадських експертиз в Україні, воно досі так і не отримало свого усестороннього та комплексного дослідження.

Формування цілей. Метою цієї статті є розкриття питання щодо удосконалення правового регулювання проведення громадської експертизи діяльності органів місцевого самоврядування в Україні.

Виклад основного матеріалу. Першим кроком щодо врегулювання конституційно-правових засад проведення громадської експертизи діяльності органів публічної влади стало прийняття Закону України «Про інформацію» від 2 жовтня 1992 р. № 2657-ХП, який наділив суб'єктів здійснення громадської експертизи основним та вирішальним правом у цій діяльності - правом доступу до офіційної інформації про діяльність органів публічної влади [7]. Трохи пізніше, проведення громадської експертизи було передбачено у сфері охорони здоров'я, коли Верховна Рада України прийняла два відповідні спеціальні закони - «Основи законодавства України про охорону здоров'я» від 19 листопада 1992 р. № 2801-ХП [8] та «Про забезпечення санітарного та епідемічного благополуччя населення» від 24 лютого 1994 p. № 4004-ХП [9].

Безпосередня ж легітимація проведення громадської експертизи діяльності органів публічної влади була здійснена шляхом прийняття двох спеціальних законів України з цього питання - «Про екологічну експертизу» від 9 лютого 1995 р. № 45/95-ВР [10] та «Про наукову і науково-технічну експертизу» від 10 лютого 1995 р. № 51/95-ВР [11], а також ухвалення низки деталізованих підзаконних нормативно-правових актів, зокрема Постанови Кабінету Міністрів України «Про науково-громадську експертизу набору продуктів харчування, набору непродовольчих товарів і набору послуг для встановлення прожиткового мінімуму» від 24 вересня 1999 р. № 1767 [12] та Наказу Міністерства охорони навколишнього природного середовища України «Про затвердження Положення про участь громадськості у прийнятті рішень у сфері охорони довкілля» від 18 грудня 2003 року № 168 [13].

Сприяло утвердженню громадської експертизи діяльності органів публічної влади як конституційно-правової форми впливу громадськості на прийняття нормативно-правових актів в окремих регіонах України, віднесення ії у Конституції Автономної Республіки Крим від 21 жовтня 1998 р., яка затверджена Законом України від 23 грудня 1998 р., до основних форм участі громадян у вирішенні питань, віднесених до компетенції АРК. Зокрема, відповідно до частини 2 статті 6 цієї Конституції, в АРК може проводитися незалежна наукова, творча і громадська експертиза, яка здійснюється фахівцями відповідних галузей знань під час підготовки і прийняття рішень 3 питань, віднесених до відання АРК [28]. Також легітимація проведення громадської експертизи діяльності органів публічної влади знайшла своє відображена i на рівні актів місцевого самоврядування - у статутах українських міст та положеннях про громадську експертизу і громадський контроль районних рад [14, с. 8].

У 2011 р. у рамках запровадження антикорупційних заходів було прийнято Закон України «Про засади запобігання та протидії корупції» від 
7 квітня 2011 р. № 3206-VI, яким передбачено можливість проведення громадської антикорупційної експертизи проектів нормативно-правових актів (стаття 15) [15]. Суттево посилило конституційно-правовий механізм проведення громадської експертизи діяльності органів місцевого самоврядування прийняття Закону України «Про доступ до публічної інформації» від 13 січня 2011 р. № 2939-VI, який визначив порядок здійснення та забезпечення права кожного на доступ до інформації, що знаходиться у володінні суб'єктів владних повноважень, інших розпорядників публічної інформації, визначених цим Законом, та інформації, що становить суспільний інтерес [16]. Удосконалення вже існуючого порядку проведення громадської експертизи було здійснено у 2012 р., коли були внесені зміни до Закону України «Про охорону навколишнього природного середовища» від 25 червня 1991 р. № 1264-XII, у якому проведення громадської екологічної експертизи віднесено до екологічних прав громадян України (стаття 9), а також визначено засади проведення екологічної експертизи (стаття 30) [17].

На рівні підзаконних нормативно-правових актів одним 3 перших кроків було зроблено Президентом України, коли у вересні 2005 р. ним було ініційовано питання про унормування загального порядку проведення громадської експертизи діяльності органів публічної влади, оцінки рівня їхньої взаємодії з громадянами та їх об'єднаннями. Зокрема, відповідно до Указу Президента України від 15 вересня 2005 р. № 1276/2005 «Про забезпечення участі громадськості у формуванні та реалізації державної політики», Кабінет Міністрів був зобов'язаний вжити заходів щодо проведення громадської експертизи до 1 листопада 2005 р. та розробити порядок сприяння іiі проведенню [18]. Водночас положення цього Указу так i залишилося нереалізованими. Неодноразові ініціативи Міністерства юстищії України щодо правового визначення порядку проведення громадської експертизи діяльності органів публічної влади на протязі наступних двох років також були безуспішними та не знайшли своєї підтримки як з боку органів публічної влади, так і громадськості.

Сприяло конституційно-правовому утвердженню громадської експертизи діяльності органів публічної влади в Україні прийняття Концепції сприяння органами виконавчої влади розвитку громадянського суспільства, яка була схвалена Розпорядженням Кабінету Міністрів України від 21 листопада 2007 р. № 1035-p. У цій Концепції було зазначено, що активно мають використовуватися, зокрема, такі форми взаємодії органів виконавчої влади з інститутами громадянського суспільства як здійснення останніми громадського контролю за діяльністю органів виконавчої влади щодо розв'язання проблем, що мають важливе суспільне значення, у формі громадського моніторингу підготовки та виконання рішень, експертизи їх ефективності, подання органам виконавчої влади експертних пропозицій [19]. Натомість реальні кроки щодо конституційно-правового регулювання порядку проведення громадської експертизи були зроблені лише на початку листопада 2008 р., коли була прийнята Постанова Кабінету Міністрів від 5 листопада 2008 p. № 976 «Про затвердження Порядку сприяння проведенню громадської експертизи діяльності органів виконавчої влади» 
[20]. Цей порядок став компромісним варіантом, який відображав як позиції органів виконавчої влади, так і громадськості.

Зокрема, згідно 3 вказаною Постанови Кабінету Міністрів, орган виконавчої влади після надходження від інституту громадянського суспільства письмового запиту щодо проведення громадської експертизи: 1) видає у тижневий строк наказ (розпорядження) про проведення такої експертизи і заходів, пов'язаних 3 підготовкою матеріалів, із зазначенням прізвища, ім'я, по батькові та посади особи, відповідальної за забезпечення взаємодії з інститутом громадянського суспільства, зміст якого доводить до відома інституту громадянського суспільства, що ініціює проведення громадської експертизи, протягом трьох днів 3 моменту його видання; 2) утворює у разі потреби робочу групу для підготовки матеріалів із залученням представників інституту громадянського суспільства, що ініціює проведення громадської експертизи; 3) розміщує у тижневий строк інформащію про надходження запиту щодо проведення громадської експертизи та заходи, здійснені органом виконавчої влади з метою сприяння ії проведенню, на власному веб-сайті; 4) подає інституту громадянського суспільства матеріали або завірені в установленому порядку їх копії з урахуванням вимог та строків, визначених Законом України «Про інформацію» [20].

Водночас Постанова Кабінету Міністрів України від 5 листопада 2008 р. № 976 «Про затвердження Порядку сприяння проведенню громадської експертизи діяльності органів виконавчої влади» носить рекомендаційний характер для органів місцевого самоврядування, які чи не найбільше взаємодіють з громадськістю. Наявне нормативне положення означає, що громадськість може ініціювати проведення громадської експертизи діяльності органів місцевого самоврядування, однак останні не зобов'язані сприяти ії проведенню, оскільки в Україні відсутнє конституційно-правове регулювання цієї сфери суспільних відносин. Тому з метою належного забезпечення принципів демократичності, прозорості та відкритості у діяльності органів місцевого самоврядування, вбачаємо за доцільне поширити конституційно-правове регулювання проведення громадської експертизи також і на сферу місцевого самоврядування. Зважаючи на те, що відповідно до пункту 15 частини 1 статті 92 Конституції України, засади місцевого самоврядування визначаються виключно законами [21], пропонуємо врегулювати порядок проведення громадської експертизи спеціальним законом для всіх органів публічної влади України.

Більше того, в Україні вже є непоодинокі випадки, коли органи місцевого самоврядування ухвалюють власні Порядки сприяння проведенню громадської експертизи діяльності органів місцевого самоврядування на основі Порядку, затвердженого Урядом. Наприклад, Первомайська міська рада Луганської області прийняла рішення «Про затвердження порядку сприяння проведенню громадської експертизи діяльності Первомайської міської ради та її виконавчих органів». Це дозволяє місцевим організаціям громадянського суспільства скористатися своїм правом на проведення громадської експертизи з дотриманням встановлених процедур [22]. 
Натомість доводиться констатувати, що протягом 2009-2014 рр. громадські експертизи діяльності органів місцевого самоврядування нажаль так і не стали дієвою конституційно-правовою формою впливу громадськості на прийняття нормативно-правових актів в Україні. Органи місцевого самоврядування неохоче йдуть назустріч громадськості, часто ігнорують іiі запити про здійснення громадських експертиз їхньої діяльності, не враховують надані пропозиції і рекомендації та не оприлюднюють інформацію щодо проведення громадської експертизи. Особливий опір 3 боку органів місцевого самоврядування викликає бажання громадськості здійснити громадську експертизу рішень, які визначають порядок нарахування житлово-комунальних тарифів та якості комунальних послуг, утримання будинків та прибудинкових територій. Таке ставлення посадових осіб місцевого самоврядування до здійснення громадських експертиз змушує громадські організації звертатися до прокуратури. Зокрема, до таких заходів змушені були вдатися ГО «Лисичанська міська асоціація підприємщів південної частини міста», ГО «Підприємці м. Кременчука «Народна Рада», Всеукраїнський громадський рух «Комунальний фронт» [1, с. 32].

3 іншого боку громадськість також повністю не використовує надані їй чинним законодавством України можливості щодо проведення громадської експертизи діяльності органів місцевого самоврядування. За 2012-2013 рр. в електронному реєстрі громадських експертиз вказується лише одна громадська експертиза, адресована органу місцевого самоврядування - запит громадської організації «Алчевський союз підприємців» на проведення громадської експертизи рішення Алчевської міської ради «Про затвердження технічної документації з нормативної грошової оцінки земель м. Алчевська». Лише один раз ініціатором проведення громадської експертизи виступив орган самоорганізації населення [23, с. 318].

Загалом аналіз чинного законодавства України дозволяє виділити шість видів громадської експертизи діяльності органів місцевого самоврядування: 1) громадська експертиза у сфері охорони здоров' я; 2) громадська екологічна експертиза; 3) громадська наукова иे науково-технічна експертиза; 4) громадська антикорупційна експертиза проектів нормативно-правових актів; 5) громадська експертиза діяльності органів виконавчої влади; 6) гендерно-правова експертиза. За часом діяльності органів місцевого самоврядування проведення громадських експертиз слід класифікувати на три види: 1) прелімінарні громадські експертизи; 2) поточні громадські експертизи; 3) ретроспективні громадські експертизи.

Вкрай важливим питанням при проведенні громадської експертизи діяльності органів місцевого самоврядування є визначення переліку громадських експертів та забезпечення відкритості та прозорості цього процесу. Об'єктивність громадської експертизи, зазначає український вчений Л. Усаченко, обумовлена тим, що вона здійснюється представниками різних громадських об'єднань щодо якості рішень органів публічної влади, актів, програм, проектів, які відповідають суспільним інтересам і впливають на все суспільство. Саме тому максимальна об'єктивність громадської експертизи можлива за умови залучення широкого загалу громадських 
експертів, що представляють різні об'єднання та рухи. Це у свою чергу дозволить забезпечити максимальну незалежність громадських експертів [4].

Окрім приналежності громадських експертів до різних соціальних та корпоративних груп не менш важливим питанням є їх кваліфікаційний рівень 3 питань, щодо яких проводиться громадська експертиза діяльності органів місцевого самоврядування. Наявність спеціальних фахових знань та відповідного професійного досвіду у громадських експертів є невід'ємною умовою належного проведення громадської експертизи діяльності органів місцевого самоврядування. Це зумовлено тим, що проведення громадських експертиз є високоінтелектуальним видом діяльності, де ключовими рисами суб'єктів іï здійснення $є$ не стільки громадська активність, скільки їх професійна обізнаність з питань, які є предметом проведення громадської експертизи, а також вміння чітко сформулювати виявлені проблеми та запропоновані шляхи їх подолання в експертному висновку.

Громадська експертиза, слушно вказує з цього приводу вітчизняний науковець О. Літвінов, є різновидом аналітичного дослідження, яке не тільки описує структурні елементи явища або процесу, що вивчається, але й з' ясовує його причини. Здійснення громадської експертизи вимагає значного часу, ретельно розробленої програми, інструментарію, попереднього уявлення про предмет дослідження [2, с. 13]. Отже, керуючись вище викладеним можна констатувати, що проведення громадської експертизи діяльності органів місцевого самоврядування є однією з найбільш інтелектуальних форм участі громадськості у місцевому самоврядуванні, яка потребує застосування спеціальних знань та відповідного професійного досвіду з використанням цілої низки різного роду аналітичних методів дослідження. Найпоширенішими методами, які використовуються при проведенні громадської експертизи діяльності органів місцевого самоврядування, слід назвати: аналіз документів, контент-аналіз, анкетування, інтерв'ю, спостереження, фокус-група тощо. Зазвичай для проведення громадської експертизи використовуються вказані методи у сукупності.

У зв'язку з цим, проведення громадської експертизи діяльності органів місцевого самоврядування створює не лише легальні можливості для громадськості здійснювати у такий спосіб вплив на прийняття нормативноправових актів, але й накладає на неї обов'язки щодо фахового, неупередженого та комплексного аналізу й оцінки відповідної проблеми. Діяльність у суспільних інтересах, вказується у Кодексі кращих практик участі громадськості у процесі прийняття рішень від 1 жовтня 2009 р., вимагає відкритості, відповідальності, ясності, підзвітності не лише від органів публічної влади, але й від неурядових організацій, із забезпеченням прозорості на всіх етапах [24, с. 6]. Тому фахове, неупереджене та прозоре проведення громадської експертизи діяльності органів місцевого самоврядування забезпечить ії утвердження як конституційно-правової форми демократії участі на місцевому рівні шляхом визнання ії корисності та ефективності як органами місцевого самоврядування, так і територіальними громадами. 
Після застосування різного роду методів дослідження та аналізу, наступним кроком у проведенні громадської експертизи діяльності органів місцевого самоврядування $є$ підготовка експертних пропозицій, які оформлюються у вигляді експертного висновку. Пропозиції, підготовлені громадськістю за результатами проведеної громадської експертизи мають бути розглянуті відповідним органом місцевого самоврядування під час підготовки програм соціально-економічного розвитку та формування бюджетів відповідного рівня.

Окрім застосування різного роду методів дослідження та аналізу, складність проведення громадської експертизи діяльності органів місцевого самоврядування полягає також у тому, що вона доволі часто комбінується 3 іншими конституційно-правовими формами демократії участі. При чому таке комбінування навіть знайшло своє відображення в актах чинного законодавства України. Зокрема, відповідно до статті 11 Закону України «Про екологічну експертизу» від 9 лютого 1995 р. № 45/95-ВР, 3 метою врахування громадської думки суб'єкти екологічної експертизи проводять публічні слухання або відкриті засідання. Участь громадськості в процесі екологічної експертизи може здійснюватись шляхом виступів у засобах масової інформації, подання письмових зауважень, пропозицій i рекомендацій, включення представників громадськості до складу експертних комісій, груп по проведенню громадської екологічної експертизи [10].

Фахове та неупереджене проведення громадської експертизи діяльності органів місцевого самоврядування за участю висококваліфікованих громадських експертів, які мають відповідний професійний досвід та представляють різних суб'єктів громадськості, в умовах сучасної України натикається на низку перепон, які потребують врахування у подальшій практиці реалізації цієї конституційно-правової форми демократії участі. Серед основних таких перепон варто назвати: фінансову витратність та технологічну складність проведення громадської експертизи діяльності органів місцевого самоврядування; некомпетентність та заангажованість громадських експертів; бюрократизм, формалізм та супротив органів місцевого самоврядування у проведенні громадської експертизи їхньої діяльності; низька громадська репрезентативність в експертних комісіях; недостатній рівень упровадження отриманих результатів у ході проведення громадської експертизи діяльності органів місцевого самоврядування. Не вирішення та ігнорування вказаних проблемних моментів суттєво послабить ефективність проведення громадської експертизи діяльності органів місцевого самоврядування.

Висновки. Громадська експертиза діяльності органів місцевого самоврядування $є$ надбанням сучасної демократії та полягає у здійсненні громадськістю комплексного дослідження у формі аналізу, оцінки та прогнозування результатів діяльності чи бездіяльності органів місцевого самоврядування, ефективності прийняття та виконання ними рішень 3 метою підготовки обгрунтованого експертного висновку з конкретними пропозиціями щодо вирішення суспільно важливих проблем для їх подальшого врахування органами місцевого самоврядування у своїй роботі. Проведення громадської експертизи $є$ необхідною формою взаємодії 
громадськості та органів місцевого самоврядування під час прийняття нормативно-правових актів, що сприяє залученню різних соціальних та корпоративних груп до експертної оцінки не лише діяльності органів місцевого самоврядування, але й прийнятих ними рішень і наслідків їх впровадження. Найбільш вразливим питанням в правовому регулюванні громадської експертизи діяльності органів місцевого самоврядування є іï недостатня правова визначеність на рівні законодавчих актів.

\section{Використані джерела:}

1. Купрій В., Паливода Л. Громадська експертиза та громадський моніторинг діяльності органів влади: навч. посібник. К.: Макрос, 2011. 192 с.

2. Громадська експертиза діяльності органів виконавчої влади в Україні: організація та проведення: практ. посіб. / О.В.Літвінов, О. В. Тинкован, Н.М. Літвінова [та ін.]; за заг. ред. О.В. Літвінова. Д.: МОНОЛІТ, 2010. 180 с.

3. Мішина Н. Законопроекти для розвитку локальної демократії в Україні. Юридичний вісник. 2014. № 2. С. 36-40.

4. Усаченко Л. М. Громадська експертиза рішень органів державної влади як форма громадського контролю. Актуальні проблеми державного управління. 2009. № 2. URL: http:/ / www.kbuapa.kharkov.ua/e-book/apdu/2009-2/doc/5/17.pdf.

5. Федоренко В.Л. Конституційне право України : підручник. Київ : Видавництво Ліра-К, 2016. 616 с.

6. Нестерович В.Ф. Конституційно-правові види громадської експертизи в Україні. Експерт. 2018. № 2. С. 67-76.

7. Про інформацію: Закон України від 2 жовтня 1992 року № 2657-XII. Відомості Верховної Ради України. 1992. № 48. Ст. 650.

8. Основи законодавства України про охорону здоров'я: Закон України від 19 листопада 1992 року № 2801-ХП. Відомості Верховної Ради України. 1993. № 4. Ст. 19.

9. Про забезпечення санітарного та епідемічного благополуччя населення: Закон України від 24 лютого 1994 року № 4004-ХП. Відомості Верховної Ради Украӥни. 1994. № 27. Ст. 218.

10. Про екологічну експертизу: Закон України від 9 лютого 1995 року № 45/95-ВР. Відомості Верховної Ради України. 1995. № 8. Ст. 54.

11. Про наукову i науково-технічну експертизу: Закон України від 10 лютого 1995 року № 51/95-ВР. Відомості Верховної Ради Украӥни. 1995. № 9. Ст. 56.

12. Про науково-громадську експертизу набору продуктів харчування, набору непродовольчих товарів і набору послуг для встановлення прожиткового мінімуму: Постанова Кабінету Міністрів України від 24 вересня 1999 року № 1767. Офіційний вісник Украӥни. 1999. № 39. Ст. 65.

13. Про затвердження Положення про участь громадськості у прийнятті рішень у сфері охорони довкілля: Наказ Міністерства охорони навколишнього природного середовища України від 18 грудня 2003 року № 168. Офіційний вiсник Украӥни. 2004. № 6. Ст. 357.

14. Конституція Автономної Республіки Крим від 21 жовтня 1998 року: затверджена Законом України від 23 грудня 1998 року № 350-XIV. Відомості Верховної Ради України. 1999. № 5-6. Ст. 43.

15. Про засади запобігання та протидії корупції: Закон України від 7 квітня 2011 року № 3206-VI. Офіиійний вісник Украӥни. 2011. № 44. Ст. 1764. 
16. Про доступ до публічної інформації: Закон України від 13 січня 2011 року № 2939-VI. Відомості Верховної Ради України. 2011. № 32. Ст. 1491.

17. Про охорону навколишнього природного середовища: Закон України від 25 червня 1991 року № 1264-XII. Відомості Верховної Ради України. 1991. № 41. Ст. 546.

18. Про забезпечення участі громадськості у формуванні та реалізації державної політики: Указ Президента України від 15 вересня 2005 року № 1276/2005. Офіиційний Вісник України. 2005. № 38. Ст. 2363.

19. Про схвалення Концепщії сприяння органами виконавчої влади розвитку громадянського суспільста: Розпорядження Кабінету Міністрів України від 21 листопада 2007 року № 1035-р. Офіиійний вісник Украӥни. 2007. № 89. Ст. 3284.

20. Про затвердження Порядку сприяння проведенню громадської експертизи діяльності органів виконавчої влади: Постанова Кабінету Міністрів України від 5 листопада 2008 року № 976. Офіиійний вісник України. 2008. № 86. Ст. 100.

21. Конституція України: прийнята на п'ятій сесії Верховної Ради України 28 червня 1996 року. Відомості Верховної Ради України. 1996. № 30. Ст. 141.

22. Правове регулювання участі громадськості у формуванні місцевої політики: проблеми та напрями реформування: Аналітична записка Національного інституту стратегічних досліджень. URL: http:/ / www.niss.gov.ua/articles/815.

23. Про внутрішне та зовнішне становище України в 2013 році: Щорічне Послання Президента України до Верховної Ради України. К.: НІСД, 2013. 576 с.

24. Code of Good Practice for Civil Participation in the Decision-Making Process (CONF/PLE(2009)CODE1): Adopted by the Conference of INGOs at its meeting on 1st October 2009. Strasburg, 2009. 17 p.

Стаття надіӥшла до редколегї 15.01.2019

Нестерович В. Ф., доктор юридических наук, доцент, заведующий кафедрой государственно-правовых дисциплин Луганского государственного университета внутренних дел имени Э.А. Дидоренко (г. Северодонецк, Украина)

Усовершенствование правового регулирования проведения общественной экспертизы деятельности органов местного самоуправления в Украине

В статье раскрыт вопрос усовершенствования правового регулирования проведения общественной экспертизы деятельности органов местного самоуправления в Украине. Указывается, что конституционно-правовое регулирование проведения общественной экспертизы началось в отдельных сферах деятельности органов публичной власти уже с первых лет обретения независимости Украины. Проведение общественной экспертизы является важной формой взаимодействия общественности и органов местного самоуправления при принятии нормативно-правовых актов, способствует привлечению различных социальных и корпоративных групп экспертной оценке не только деятельности органов местного самоуправления, но и принимаемых ими решений и последствий их внедрения. Отмечено, что наиболее уязвимым вопросом в правовом регулировании общественной экспертизы деятельности органов местного самоуправления является ее недостаточная правовая определенность на уровне законодательных актов.

Ключевые слова: правовое регулирование, общественная экспертиза, общественность, органы публичной власти, органы местного самоуправления, Украина. 
Nesterovych V. Improvement of Legal regulation of the Public Examination of the Activities of local Self-government in Ukraine

The article reveals the question of improvement of legal regulation of the public examination of the activities of local self-government in Ukraine. The author points out that the constitutional and legal regulation of public examination began in certain areas of activity of public authorities from the very first years of independence of Ukraine. Conducting public expertise is an important form of interaction between the public and local authorities in the adoption of legal acts, contributes to attracting various social and corporate groups to peer review not only the activities of local governments, but also their decisions and the consequences of their implementation. The article notes that the most vulnerable issue in the legal regulation of public examination of the activities of local governments is its insufficient legal certainty at the level of legislative acts.

The author concludes that public expertise of the activities of local self-government bodies is the property of modern democracy. Public expertise of the activities of local selfgovernment bodies means carrying out by the public of a comprehensive study in the form of analysis, evaluation and forecasting of the results of activity or inactivity of local selfgovernment bodies, the effectiveness of their adoption and implementation of decisions. The purpose of the public examination is to prepare a substantiated expert opinion with concrete proposals for the solution of socially important problems for their further consideration by the local self-government bodies in their work. Conducting a public examination is a necessary form of interaction between the public and local self-government bodies when adopting regulatory and legal acts. Conducting public examination helps to attract various social and corporate groups to the expert assessment of not only the activities of local selfgovernment bodies, but also the decisions taken by them and the consequences of their implementation.

Key words: legal regulation, public expertise, public, public authorities, local authorities, Ukraine.

УДК 342.8

Пекарчук В.М. доктор історичних наук, доцент, професор кафедри теорії та історії держави і права, конституизійного права Академї̈ Державної пенітенціарної служби

(м. Чернігів, Україна)

Пекарчук А.В.

студентка 2 курсу Інституту прокуратури та кримінальної юстиції Національного юоридчного університету імені Ярослава Мудрого

(м. Харків, Україна)

\section{ТРАНСФОРМАЦІЯ ВИБОРЧОЇ СИСТЕМИ ВЕРХОВНОЇ РАДИ УКРАЇНИ ПЕРІОДУ НЕЗАЛЕЖНОСТІ}

У статті на основі різнопланових джерел досліджуються актуальні питання виборчої системи до вітчизняного парламенту упродовж сучасного періоду незалежності, і на цій основі запровадження більш ефективної моделі пропорційної виборчої системи 3 відкритими списками. Проаналізовано недоліки на різних етапах становлення та розвитку парламентської виборчої системи. Обгрунтовано важливість невідкладного ухвалення Виборчого кодексу

(C) Пекарчук B. М.,

Пекарчук А. В., 2019 